\title{
A case with hemorrhagic varicella treated with continuous infusion of acyclovir: A case report
}

\author{
Sürekli asiklovir infüzyon ile tedavi edilen bir hemorajik suçiçeği olgusu
}

\author{
Ahu KARA ${ }^{1 \oplus, \text { Bengü DEMIRAĞ }}{ }^{2}$, Sultan AYDIN ${ }^{2}$, Rana İşGÜDER ${ }^{3}$, Gökhan CEYLAN ${ }^{3}$, Yeşim OYMAK $^{2}$, \\ Tuğba HILLKAY ${ }^{2}$, Nuri BAYRAM ${ }^{1} \oplus$, Hasan AĞIN ${ }^{3}$, İker DEVRIM ${ }^{1} \odot$
}

${ }^{1}$ Dr. Behçet Uz Çocuk Hastanesi, Çocuk Enfeksiyon Hastalıkları, İzmir, Türkiye

${ }^{2}$ Dr. Behçet Uz Çocuk Hastanesi, Çocuk Hematoloji ve Onkoloji Ünitesi, İzmir, Türkiye

${ }^{3}$ Dr. Behçet Uz Çocuk Hastanesi, Çocuk Yoğunbakım Ünitesi, İzmir, Türkiye

\begin{abstract}
Hemorrhagic varicella is one of the serious and frequently fatal forms of the VZV infections especially in immunocompromised patients. We report a 9-year-old boy with acute lymphoblastic leukemia suffered from hemorrhagic varicella infection. During follow-up period progressed acute respiratory distress syndrome developed in the patient. Continuous acyclovir infusion therapy was applied instead of intermittent acyclovir administration. Continuous infusion of acyclovir could be a life-saving treatment strategy in disseminated or hemorrhagic varicella infections in immunocompromised children.
\end{abstract}

Keywords: Acyclovir, hemorrhagic varicella, leukemia

ÖZ

Alındığı tarih: 10.09.2017

Kabul tarihi: 11.04 .2018

Hemorajik suçiçeği, özellikle bağışıklık sistemi baskılanmış hastalarda varisellazoster-virüs enfeksiyonlarının ciddi ve sıklıkla fatal seyreden formlarından biridir. Hemorajik suçiçeği enfeksiyonu geçiren akut lenfoblastik lösemili 9 yaşında bir erkek hasta sunduk. Hastanın takibinde akut solunum sıkıntısı sendromu gelişti. Aralıklı asiklovir tedavisi yerine sürekli asiklovir infüzyonu tedavisi uygulanmıştır. Sürekli asiklovirin infüzyonu bağışıklığı baskılanmış çocuklarda dissemine veya hemorajik suçiçeği enfeksiyonlarında yaşam kurtarıcı bir tedavi stratejisi olabilir.

Anahtar kelimeler: Asiklovir, hemorajik suçiçeği, lösemi
Yazışma adresi: Uzm. Dr. Ahu Kara, İsmet Kaptan Mah., Sezer Doğan Sok. No:11, Konak İzmir - Türkiye

e-mail: ahukara01@hotmail.com

Yazarların ORCID bilgileri:

A.K. 0000-0002-8671-3604

N.B. $0000-0003-1802-2518$

İ.D. 0000-0002-6053-8027

\section{INTRODUCTION}

Infections with varicella-zoster virus (VZV) are usually considered benign infections especially in immunocompetent hosts. However primary varicellazoster virus infections may cause potentially lifethreatening complications in immunocompromised patients who are under intensive multiagent chemotherapy including corticosteroids (1). Hemorrhagic varicella is one of the serious and frequently fatal forms of the VZV infections.

Before introduction of antiviral therapy, the mortality rate of varicella infections in children with cancer was reported to range between $7 \%$ to $55 \%$ depending on the presence of visceral involvement ${ }^{(2-5)}$. Continuous infusion of acyclovir may represent a treatment approach for patients who have severe viral infections not responding to conventional administration of the drug ${ }^{(6)}$.

We report a child with acute lymphoblastic leukemia (ALL) who suffered from hemorrhagic varicella infection and successfully treated with a continuous infusion of acyclovir instead of intermittent acyclovir administration.

\section{CASE}

A 9-year-old boy with standard risk pre-B ALL, was admitted to our hospital with fever, abdominal pain, and vesicular skin rash for 3 days, while he had been under chemotherapy consisting of methotrexate and 6-mercaptopurine at the first year of maintenance 
therapy according to the ALL-IC BFM 2009 protocol. On physical examination, he had diffuse hemorrhagic, vesicular skin rashes consistent with VZV infection (Figure 1). His hematologic, and biochemical test results were as follows: serum hemoglobin, $14.1 \mathrm{~g} / \mathrm{dl}$; platelet counts, $101 \times 10^{9} / \mathrm{L}$; white blood cell counts, $2.6 \times 10^{9} / \mathrm{L}$; absolute lymphocyte counts, $0.47 \times 10^{9} / \mathrm{L}$; absolute neutrophil counts, $2.0 \times 10^{9} / \mathrm{L}$; alanine aminotransferase, $963 \mathrm{U} / \mathrm{L}$, and aspartate aminotransferase, $730 \mathrm{U} / \mathrm{L}$. Levels of serum electrolytes, glucose, creatinine, and blood urea nitrogen were within normal limits. His chest radiograph (CXR) was also normal. The patient's chemotherapy was discontinued and intravenous acyclovir therapy $\left(1500 \mathrm{mg} / \mathrm{m}^{2} / \mathrm{d}\right.$ in 3 divided doses) was initiated. On third day of admission, his oxygen saturation began

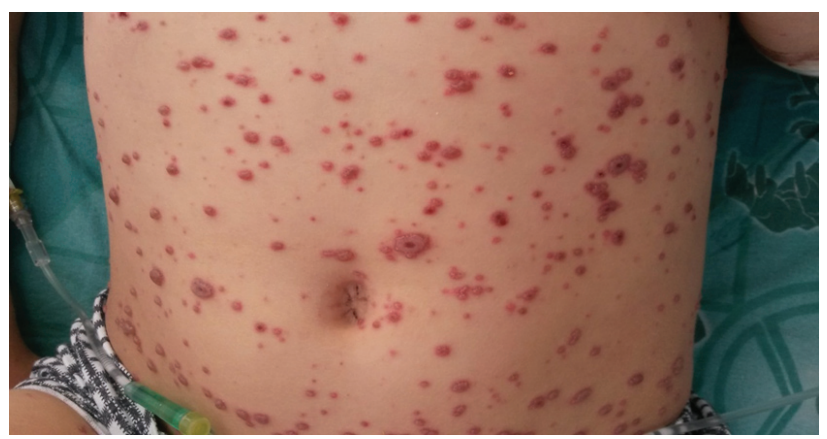

Figure 1. Diffuse hemorrhagic, vesicular skin rashes on his body.

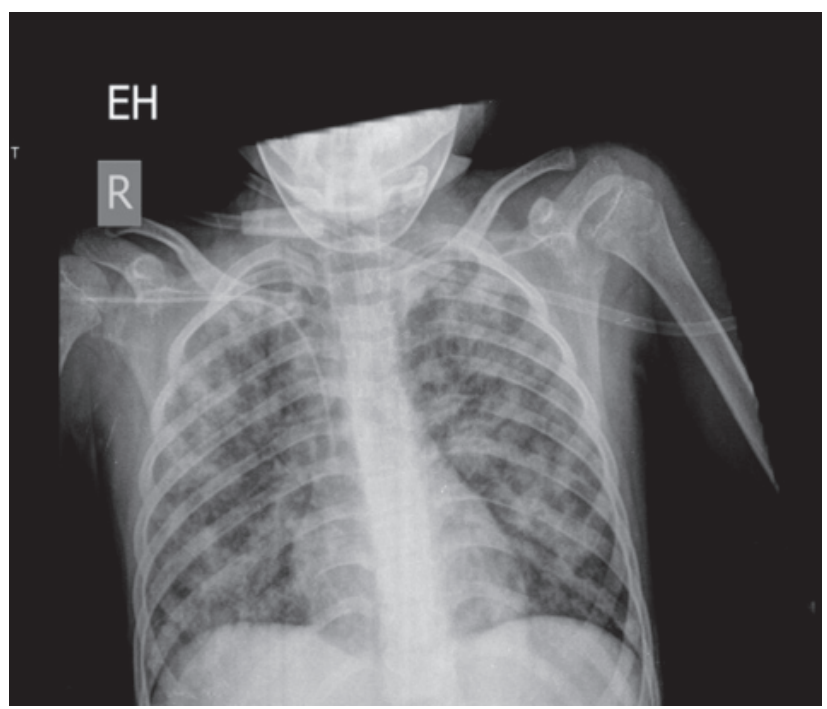

Figure 2. A repeat chest radiograph showing diffuse pulmonary infiltrates. to decrease and he became tachypneic with a respiratory rate of $40 / \mathrm{min}$. A repeat CXR showed new diffuse pulmonary reticulonodular infiltration (Figure 2). Continuous infusion of acyclovir ( $2 \mathrm{mg} / \mathrm{kg} /$ day $)$ was initiated, however the patient's clinical status deteriorated, fever and new infiltrations developed under acyclovir therapy, so vancomycin and cefepime therapy was added to the treatment regimen. The patient had respiratory failure and diagnosed as acute respiratory distress syndrome (ARDS) (Figure 3). Any pathogen could not be isolated from his blood and urine cultures.

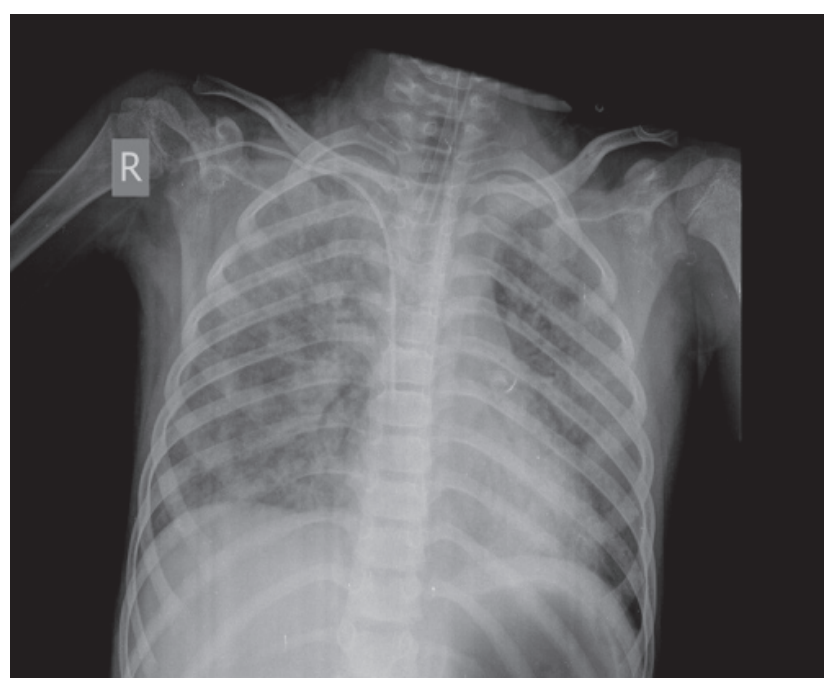

Figure 3. A repeat chest radiograph showing diffuse pulmonary infiltrates in both lung fields.

He was intubated and followed up in pediatric intensive care unit with assisted mechanical ventilation on the $6^{\text {th }}$ day of his hospitalization. His antimicrobial therapy was changed to linezolide, ciprofloxacin and amikacin with the diagnosis of ventilatorassociated pneumonia. On the $7^{\text {th }}$ day of intubation his hypoxia recovered and parameters of respiratory function were normalized. Continuous infusion of acyclovir was continued during this two-week period. After two weeks of therapy, the CXR findings were within normal limits, and the patient remained afebrile, with a gradual disappearance of his abnormal respiratory signs. The patient received a full course of parenteral continuous infusion of acyclovir for 18 days and then discharged from the PICU. No increase in the creatinine and serum urea levels was 
observed and the child did not have any other side effects related to continuous acyclovir infusion. At the end of the acyclovir therapy, the scheduled chemotherapy course was continued without any complications.

\section{DISCUSSION}

Hemorrhagic varicella and dissemination of the primary infection are much more common among immunocompromised patients compared to immunocomponent hosts. The lungs, liver, brain, and heart are usually involved in progressive varicella. The mortality rate of disseminated varicella is also high in immunocompromised children. Before introduction of antiviral therapy, the mortality rate of varicella infections in children with cancer was reported to be ranging from $7 \%$ to $55 \%$ depending on the presence of visceral involvement ${ }^{(2-5)}$. Fortunately mortality rate of varicella-infections in children with immune suppression has decreased significantly $(<1 \%)$ after introduction of antiviral treatment with acyclovir and varicella-zoster immune globulin (VZIG).

Acyclovir is a highly potent inhibitor of VZV and early treatment with acyclovir has been shown to prevent dissemination and progression of the disease (7). Resistance to acyclovir is not uncommon in immunocompromised patients, and has been associated with prior acyclovir treatment and severity of immunosupression ${ }^{(8)}$. The mechanism of action of acyclovir appears to be more complicated in immunocompromised patients than in normal hosts, and higher doses and improved regimens of acyclovir may be necessary in these patients ${ }^{(9-11)}$.

The intermittent administration of parenteral acyclovir has shown widespread safety and utility in the treatment of VZV infections. In addition to intermittent usage, the usefulness of continuous acyclovir infusion for 16 immunocompromised patients with HSV or varicella-zoster virus infections was previously suggested by Spector et al. ${ }^{(10)}$. In our case; despite appropriate administration of acyclovir therapy, VZV infection rapidly progressed to ARDS, thus, continuous acyclovir infusion was initiated.

Continuous acyclovir infusion is not necessary in most clinical situations. However, we believe that continuous acyclovir infusion may represent a viable alternative in selected situations. As in our patient, continuous acyclovir infusion may be beneficial and preferable for severe, life-threatening VZV infections that are resistant to treatment with the conventional regimen ${ }^{(12,13)}$. The potential risks of continuous infusion appear to be nephrotoxicity and neutropenia. Nephrotoxicity and neutropenia were not observed in this patient. Nephrotoxicity can be minimized by close attention to dose, renal function, and hydration status of the patient.

In conclusion, continuous acyclovir infusion could be a life-saving treatment strategy in disseminated or hemorrhagic varicella infections in immunocompromised children. However, pros and cons of continuous acyclovir therapy should be evaluated individually for pediatric patients with malignant diseases.

\section{REFERENCES}

1. Wiegering V, Schick J, Beer M, et al. Varicella-zoster virus infections in immunocompromised patients - a single centre 6-years analysis. BMC Pediatr. 2011;11:31. https://doi.org/10.1186/1471-2431-11-31

2. Feldman S, Hughes WT, Daniel CB. Varicella in children with cancer: Seventy-seven cases. Pediatrics. 1975;56:38897.

3. Katsimpardi K, Papadakis V, Pangalis A, et al. Infections in a pediatric patient cohort with acute lymphoblastic leukemia during the entire course of treatment. Support Care Cancer. 2006; 14:277-84.

https://doi.org/10.1007/s00520-005-0884-6

4. Matsuzaki A, Suminoe A, Koga Y, et al. Fatal visceral varicella-zoster virus infection without skin involvement in a child with acute lymphoblastic leukemia. Pediatr Hematol Oncol. 2008;25:237-42. https://doi.org/10.1080/08880010801938215

5. Meir HM, Balawi IA, Meer HM, Nayel H, Al-Mobarak MF. Fever and granulocytopenia in children with acute lymphoblastic leukemia under induction therapy. Saudi Med J. 2001;22:423-7.

6. Wagstaff AJ, Faulds D, Goa KL. Aciclovir: a reappraisal of its antiviral activity, pharmacokinetic properties and therapeutic efficacy. Drugs. 1994;47:153-205. https://doi.org/10.2165/00003495-199447010-00009

7. Tokat O, Kelebek N, Turker G, Kahveci SF, Ozcan B. Intravenous immunoglobulin in adult varicella pneumonia complicated by acute respiratory distress syndrome. J Int Med Res. 2001;29:252-5. https://doi.org/10.1177/147323000102900313

8. Saint-Le' ger E, Caumes E, Breton G et al. Clinical and virologic characterization of aciclovir-resistant varicella-zoster viruses isolated from 11 patients with acquired immunodeficiency syndrome. Clin Infect Dis. 2001;33:2061-7. 
https://doi.org/10.1086/324503

9. Fletcher CV, Englund JA, Bean B, Chinnock B, Brundage DM, Balfour HH Jr. Continuous infusion of high-dose acyclovir for serious herpesvirus infections. Antimicrob Agents Chemother. 1989;33:1375-8.

https://doi.org/10.1128/AAC.33.8.1375

10. Spector SA, Hintz M, Wyborny C, Connor JD, Keeney RE, Liao S. Treatment of herpes virus infections in immunocompromised patients with acyclovir by continuous intravenous infusion. Am J Med. 1982;73(Suppl 1A):275-80.

https://doi.org/10.1016/0002-9343(82)90105-X
11. Engel JP, Englund JA, Fletcher CV, Hill EL. Treatment of resistant herpes simplex virus with continuous-infusion acyclovir. JAMA. 1990;263:1662-4. https://doi.org/10.1001/jama.1990.03440120084042

12. Kakinuma H, Itoh E. A continuous infusion of acyclovir for severe hemorrhagic varicella. N Engl J Med. 1997;336:732-3. https://doi.org/10.1056/NEJM199703063361016

13. Krolewiecki AJ, Braffman MN. More on continuous-infusion acyclovir for severe varicella. Engl J Med. 1997;337:203-4. https://doi.org/10.1056/NEJM199707173370316 